\title{
DOES PRE-COMPETITIVE ANXIETY INTERFERE IN THE PERFORMANCE OF BOXING ATHLETES IN BRAZIL? A PILOT STUDY
}

OriginAL ARTICLe

ARTIGO ORIGINAL Artículo Original

\author{
A ANSIEDADE PRÉ-COMPETITIVA INTERFERE NO RENDIMENTO DOS ATLETAS DE BOXE NO BRASIL? \\ ESTUDO PILOTO
}

\begin{abstract}
¿LA ANSIEDAD PRECOMPETITIVA INTERFIERE EN EL RENDIMIENTO DE LOS ATLETAS DE BOXEO EN BRASIL? ESTUDIO PILOTO
\end{abstract}

Andres Armas Alejo $0^{1,2}$ (ID

(Physical Education Professional)

Felipe José Aidar 1,2,3, (ID

(Physical Education Professional)

Dihogo Gama de Matos² (DD

(Physical Education Professional)

Marcelo Danillo dos Santos ${ }^{1,2}$ (ID

(Physical Education Professional)

Dilton dos Santos Silva ${ }^{1,2}$ (ID

(Physical Education Professional)

Raphael Fabrício de Souza ${ }^{2,3}$ (ID

(Physical Education Professional)

Jymmys Lopes dos Santos 5,6 (iD)

(Physical Education Professional)

Lúcio Marques Vieira Souza ${ }^{5,6}$ (ID

(Physical Education Professional)

Cleberson Franclin Tavares Costa ${ }^{7}$ (ID)

(Physical Education Professional)

Albená Nunes da Silva ${ }^{8}$ (ID

(Physical Education Professional)

1. Universidade Federal de Sergipe (UFS), Postgraduate Program at Master's level in Physical Education,

São Cristovão, Sergipe, SE, Brazil. 2. Universidade Federal de Sergipe (UFS), Performance, Sport, Health and Paralympic Sports Research Group (GEPEPS), São Cristovão,

Sergipe, SE, Brazil.

3. Universidade Federal de Sergipe (UFS), Department of Physical Education, São Cristovão, Sergipe, SE, Brazil.

4. Universidade Federal de Sergipe (UFS), Postgraduate Program in Physiological Sciences, São Cristóvão, Sergipe, SE, Brazil. 5. Universidade Federal de Sergipe (UFS), Postgraduate Program in Biotechnology, São Cristóvão, Sergipe, SE, Brazil.

6. Centro Universitário Maurício de Nassau, Aracaju, SE, Brazil.

7. Universidade Tiradentes, Postgraduate Program in Health and Environment, Aracaju, SE, Brazil. 8. Universidade Federal de Ouro Preto, Exercise, Inflammation and Immunology Laboratory, Sports Center, Minas Gerais, MG, Brazil.

\section{Correspondence:}

Felipe J. Aidar. Cidade Universitária Prof. José Aloísio de Campos. Av. Marechal Rondon, s/n Jardim Rosa Elze, São Cristóvão, SE, Brazil. 49100-000. fjaidar@gmail.com

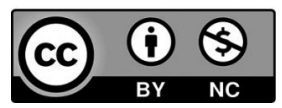

\begin{abstract}
Introduction: Pre-competitive anxiety is one of the psychological factors that can greatly influence athletes' performance, especially when it comes to individual sport like boxing. Objective: To analyze the level of pre-competitive anxiety in male athletes in the adult and young adult categories, and their correlation with the final results of the last Brazilian National Championship. Methods: A total of 60 young adult athletes participated in the study: 38 non-medalists $(17.17 \pm 0.54$ years and $66.38 \pm 13.21 \mathrm{~kg})$ and 22 medalists $(17.48 \pm 0.54$ years and $66.21 \pm 12.96 \mathrm{~kg}$ ). The "adults" group consisted of 35 athletes: 11 non-medalists ( $22.60 \pm 4.65$ years and $68.33 \pm 14.08 \mathrm{~kg}$ ) and 24 medalists $(22.60 \pm 4.82$ years and $67.33 \pm 13.13 \mathrm{~kg}$ ). Results: The levels of cognitive anxiety in the young adult athletes group presented significant differences: medalists presented lower scores than non-medalists (12.77 \pm 2.62 and $15.92 \pm 5.20$, respectively). In the adults group, medalists presented higher scores than non-medalists ( $15.23 \pm 4.42$ and $12.00 \pm 4.11$ ). Significant differences were observed in somatic anxiety levels between the young adult medalists and the other groups $(p=0.038)$. In addition, levels of self-confidence were high in all groups (young adult non-medalists $=29.42 \pm 4.82$; adult non-medalists $=26.14 \pm 4.94$, young adult medalists $=31.59 \pm 4.24$ and adult medalists $=28.91 \pm 4.88$ ). Conclusion: We conclude that self-confidence may interfere with anxiety levels, considering that medal-winning boxers are less prone to cognitive anxiety than non-medalists, and that both groups have high levels of self-confidence. Level of evidence l; High quality randomized trial with statistically significant difference or no statistically significant difference but narrow confidence intervals.
\end{abstract}

Keywords: Anxiety; Sports performance; Boxing; Youth.

\section{RESUMO}

Introdução: A ansiedade pré-competitiva éum dos fatores psicológicos que pode exercer grande influência sobre o rendimento dos atletas, principalmente, quando se trata de esporte individual como o boxe. Objetivo: Analisar o nivel de ansiedade pré-competitiva em atletas do sexo masculino nas categorias adulto e juvenil e sua correlação com os resultados finais do último Campeonato Brasileiro. Métodos: Participaram do estudo 60 atletas juvenis: 38 não medalhistas $(17,17 \pm 0,54$ anos e 66,38 $\pm 13,21 \mathrm{~kg})$ e 22 medal histas $(17,48 \pm 0,54$ anos e 66,21 $\pm 12,96 \mathrm{~kg})$. O grupo "adultos" foi composto por 35 atletas: 11 não medalhistas $(22,60 \pm 4,65$ anos e 68,33 $\pm 14,08 \mathrm{~kg})$ e 24 medaIhistas $(22,60 \pm 4,82$ anos e $67,33 \pm 13,13 \mathrm{~kg})$. Resultados: Os niveis de ansiedade cognitiva no grupo de atletas juvenis apresentaram diferenças significativas: os medalhistas apresentaram escores mais baixos do que os não medalhistas $(12,77 \pm 2,62$ e 15,92 $\pm 5,20$, respectivamente). No grupo de adultos, os medalhistas apresentaram maiores escores do que os não medalhistas $(15,23 \pm 4,42$ e 12,00 $\pm 4,11)$. Diferenças significativas foram observadas nos níveis de ansiedade somática entre os medalhistas juvenis eos outros grupos $(p=0,038)$. Além disso, os níveis de autoconfiança apresentaram-se altos em todos os grupos (não-medalhistas juvenis $=29,42 \pm 4,82$; não-medalhistas adultos $=26,14 \pm$ 4,94, medalhistas juvenis $=31,59 \pm 4,24$ e medalhistas adultos $=28,91 \pm 4,88$ ). Conclusão: Concluiu-se que a autoconfiança pode interferir nos niveis de ansiedade, considerando que boxeadores medalhistas são menos propensos a ansiedade cognitiva do que os não-medalhistas e que ambos os grupos apresentam altos níveis de autoconfiança. Nível de evidência l; Estudo clínico randomizado de alta qualidade com ou sem diferença estatisticamente significante, mas com intervalos de confiança estreitos.

Descritores: Ansiedade; Desempenho esportivo; Boxe; Juventude.

\section{RESUMEN}

Introducción: La ansiedad precompetitiva es uno de los factores psicológicos que puede ejercer gran influencia sobre el rendimiento de los atletas, principalmente, cuando se trata de deportes individuales como el boxeo. Objetivo: Analizar el nivel de ansiedad precompetitiva en atletas del sexo masculino en las categorías adulto y juvenil, y su correlación con los resultados finales del último Campeonato Brasileño. Métodos: Participaron en el estudio 60 atletas 
juveniles: 38 no medallistas $(17,17 \pm 0,54$ años y 66,38 $\pm 13,21 \mathrm{~kg})$ y 22 medallistas $(17,48 \pm 0,54$ años y 66,21 \pm 12,96 kg). El grupo "adultos" fue compuesto por 35 atletas: 11 no medallistas $(22,60 \pm 4,65$ años y 68,33 $\pm 14,08 \mathrm{~kg})$

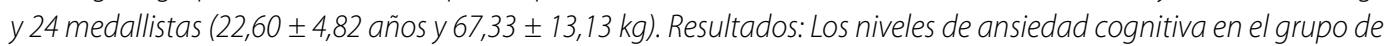
atletas jóvenes presentaron diferencias significativas: los medallistas presentaron puntuaciones más bajas que los no medallistas (12,77 $\pm 2,62$ y 15,92 \pm 5,20 respectivamente). En el grupo de adultos, los medallistas presentaron puntuaciones más altas que los no medallistas (15,23 $\pm 4,42$ y 12,00 $\pm 4,11)$. Se observaron diferencias significativas en los niveles de ansiedad somática entre medallistas juveniles y los otros grupos $(p=0,038)$. Además, los niveles de autoconfianza se presentaron altos en todos los grupos (juveniles no medallistas $=29,42 \pm 4,82$; adultos no medallistas $=26,14 \pm 4,94$, medallistas juveniles $=31,59 \pm 4,24$ y medallistas adultos $=28,91 \pm 4,88)$. Conclusión: Se concluyó que la autoconfianza puede interferir en los niveles de ansiedad, considerando que los boxeadores medallistas son menos propensos a la ansiedad cognitiva que los no medallistas y que ambos grupos tienen altos niveles de autoconfianza. Nivel de evidencia l; Estudio clínico aleatorio de alta calidad con o sin diferencia estadísticamente significativa, pero con intervalos de confianza estrechos.

Descriptores: Ansiedad; Rendimiento deportivo; Boxeo; Juventud.

\section{INTRODUCTION}

Anxiety, particularly competitive anxiety, has been the subject of many studies in sports psychology $y^{1,2}$ and has been considered as a decisive factor that tends to interfere with athletic performance., ${ }^{3,4}$ Most athletes suffer from pressure, fear, and anxiety caused by the obligation to win, which may be explained by the exaltation of the emotion of victory and the discouragement of defeat, ${ }^{5}$ even individual sport athletes, such as in the case of bodybuilding, tend to present higher levels of anxiety than athletes in collective sports. ${ }^{6}$ However, boxing requires dedication, with prolonged diets and sometimes with the use of illicit ergogenics without medical supervision, which may even have undesirable effects. ${ }^{6}$

Although studies focused on boxing are scarce, the concern with sports performance points in the direction that performance can be affected by intervening factors, among them psychosocial aspects. ${ }^{7-9}$ Studies have shown that anxiety interferes with the results: the psychic condition is related to the sporting performance. ${ }^{10,11}$

Anxiety is characterized by two aspects: cognitive anxiety (CA) is characterized by excessive preoccupation with performance, apprehension and negativism; and somatic anxiety (SA) has as its main characteristic transient changes in physiological activation, such as an increase in heart rate, respiratory changes, excessive sweating, tremors, increased blood pressure, muscle tension, among others, that are subdivided into anxiety-state (AS) and anxiety-trait (AT). In AS, somatic and cognitive changes are manifested by the anxiogenic environment, triggering in specific situations; AT can manifest itself in different situations, such as "part of the personality, as a tendency of behavior", a predisposition of the individual to behave disproportionately in different situations. ${ }^{12,13}$

Therefore, anxiety is an important tool in high-performance sports results. However, there is still no consensus in the literature about the effects of pre-competitive anxiety on performance in boxing athletes. In this sense, the objective of this study was to analyze the level of pre-competitive anxiety in male boxing athletes of the adult and juvenile categories, and their correlation with the final results of the Brazilian National Championship of 2017.

\section{METHODS}

A total of 60 juvenile athletes participated in the study: 38 were non-medalists-NM (17.17 \pm 0.54 years and $66.38 \pm 13.21 \mathrm{~kg})$ and 22 were medalists (juvenile group medalists-Med, $17.48 \pm 0.54$ years and $66.21 \pm 12.96$ $\mathrm{kg}$ ). The "adults" group consisted of 35 athletes: 11 were non-medalists (adult NM, 22.60 \pm 4.65 years and $68.33 \pm 14.08 \mathrm{~kg}$ ) and 24 were medalists (adult Med, $22.60 \pm 4.82$ years and $67.33 \pm 13.13 \mathrm{~kg}$ ). Only federated athletes who provided informed consent were included in the study. The adopted procedures followed the norms of ethics in researches with humans according to Resolution no. 466, of 12/12/2012 of the National Council of Health, normative of research involving human beings, in agreement with the ethical principles contained in the Declaration of Helsinki (1964, reformulated in 1975, 1983, 1989, 1996, 2000, 2008, and 2013) of the World Medical Association.

The study was approved by the Federal University of Sergipe Research Ethics Committee (protocol 01723312.2.0000.0058) in accordance with the guidelines on experiments involving humans.

We used the Competitive State Anxiety Inventory Questionnaire-II (CSAI-2), which was translated and validated by Vasconcelos-Raposo and Fernandes. The questionnaire consisted of 27 questions divided into three sub-scales, i.e., cognitive anxiety, somatic anxiety, and self-confidence. Each subject could choose between four levels that corresponded with their momentary condition: 1 = nothing, 2 = something, 3 = moderate, and $4=$ greatly. The sub-scale score was obtained based on the sum of the ratings, with the scores varying from 9 to 36. The cognitive anxiety score was determined based on the sum of the ratings of questions 1 , $7,10,13,16,19,22$, and 25 . The somatic anxiety score was determined based on the sum of the ratings of questions $2,5,8,11,14,17,20,23$, and 26. The self-confidence score was determined based on the sum of the ratings of questions $3,4,6,9,12,15,18,21,24$, and 27 . For interpretation purposes, the cognitive anxiety, somatic anxiety, and self-confidence score levels were categorized as low (9 to 18 points), average (19 to 27 points), or high (28 to 36 points).

Data were collected (in the pre-competition stage) during the general weighing that is performed the day before the official start of the championship, for the adult and juvenile categories. The questionnaire was filled out by an evaluator with at least 20 applications and with an intra-rater correlation higher than 0.954. To ensure that the procedures were effective, the data were collected by a responsible research team and a psychologist who administered the questionnaires. The data collection was completed in the same place where the competition occurred.

\section{Statistical analysis}

The central tendency measures, mean \pm standard deviation $(X \pm S D)$, were used. To verify the normality of the variables, the Shapiro Wilk test was used, considering the sample size. To verify the possible differences between the groups divided by classification (medalist and non-medalists), one way ANOVA and post hoc test of Bonferroni were used. To verify the size of the effect, the Cohen $\mathrm{f}^{2}$ test was used, in addition 
to the cut points 0.02 to 0.15 with a small effect, from 0.15 to 0.35 as median and greater than 0 . The statistical treatment was performed using the Statistical Package for Social Science (SPSS), version 22.0. A p $<0.05$ was considered.

\section{RESULTS}

Table 1 shows the results of CSAI-2 on the cognitive, somatic, and self-confidence domains.

The levels of cognitive anxiety in the juvenile group presented significant differences, with medalists presenting lower scores than non-medalists (12.77 and 15.92 respectively). In the adult group, medalists presented higher scores than non-medalists (15.23 and 12.00). Significant differences were observed in somatic anxiety levels between juvenile medalists and the other groups ( $p=0.038$ ). In addition, levels of self-confidence were high in all groups (juvenile $\mathrm{NM}=29.42$, adult $\mathrm{NM}=26.14$, juvenile $\mathrm{Med}=31.59$ and adult Med = 28.91).

Significant differences were not observed between the groups, although juvenile medalists presented higher values than the other athletes in the item Self-confidence.

Figure 1 and 2 shows the results of CSAI-2 on confidence interval cognitive and Somatic Anxiety domains among Non-Medalist and Medalist on adult and junior categories.

The confidence interval showed a higher probability of the result (being a medalist) depending on the lower cognitive and somatic anxiety in the Junior category compared to the Senior category.

Figure 3 shows the results of CSAI-2 on confiance Interval Self Confidence domains between Non-Medalist and Medalist on adult and junior categories.

The confidence interval showed no differences between Adult and Junior regarding performance and self-confidence.

Table 1. Results in relation to the classification (Medalists and non-medalists) of the items of the pre-competitive anxiety scale of CSAI-2 for Juvenile and Adult athletes in the Brazilian Boxing Championships of 2017.

\begin{tabular}{c|c|c|c|c|c}
\hline & $\begin{array}{c}\text { Juvenile not } \\
\text { medalist }\end{array}$ & $\begin{array}{c}\text { Juvenile } \\
\text { medalist }\end{array}$ & $\begin{array}{c}\text { Non-medalist } \\
\text { adults }\end{array}$ & $\begin{array}{c}\text { Adult } \\
\text { Medalist }\end{array}$ & $\mu_{\mathbf{p}} \mathbf{2}$ \\
\hline Cognitive Anxiety & $15.92 \pm 5.20^{\mathrm{a}}$ & $12.77 \pm 2.62$ & $12.00 \pm 4.11$ & $15.23 \pm 4.42$ & $0.121^{*}$ \\
\hline Somatic Anxiety & $14.03 \pm 4.63$ & $12.05 \pm 2.46^{\mathrm{b}}$ & $14.00 \pm 2.77$ & $13.85 \pm 2.94$ & 0.031 \\
\hline Self confidence & $29.42 \pm 4,82$ & $31.59 \pm 4.24$ & $26.14 \pm 4,94$ & $28.91 \pm 4.88$ & --- \\
\hline a: $p=0,032 ; b: p=0,038$ (ANOVA one way, Post Hoc Bonferroni); ${ }^{*}$ small effect.
\end{tabular}

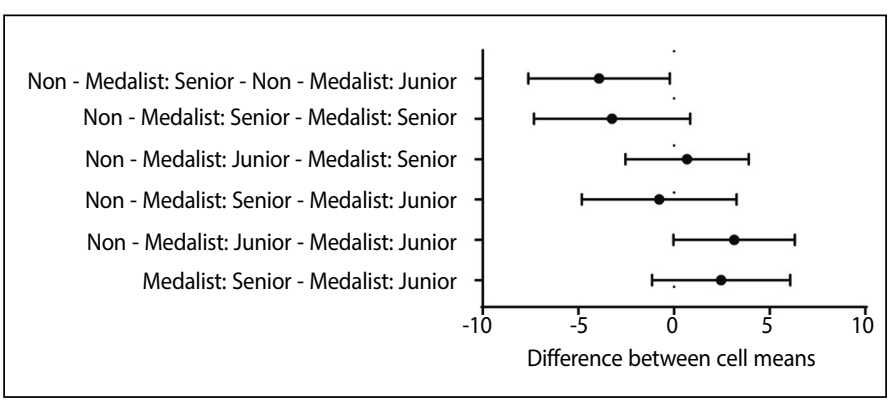

Figure 1. Confidence Interval Cognitive Anxiety between Non-Medalist and Medalist on adult and junior categories.

\section{DISCUSSION}

The main objective of our study was to evaluate the level of pre-competitive anxiety in male and female adult boxing athletes and their correlation with the final results of the Brazilian National Championship in 2017.

The levels of cognitive anxiety presented significant differences, with medalists presenting lower scores than non-medalists in the juvenile group (12.77 and 15.92 respectively) and in the Adult group, medalists had scores higher than non-medalists (15.23 and 12.00).

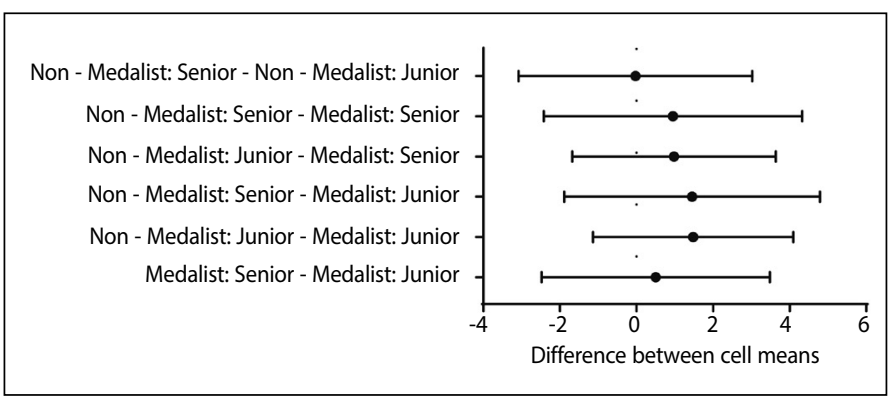

Figure 2. Confidence Interval Somatic Anxiety between Non-Medalist and Medalist on adult and junior categories.

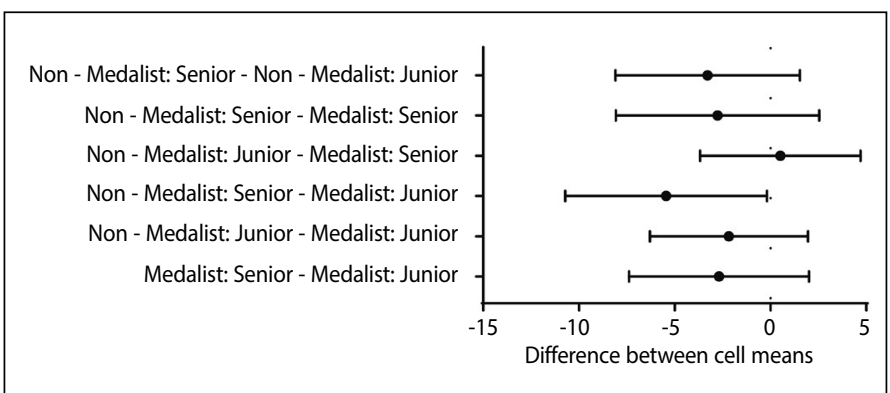

Figure 3. Confidence Interval Somatic Self Confidence between Non-Medalist and Medalist on adult and junior categories.

The main results showed that cognitive anxiety levels of juvenile NM were higher than in the other groups. This result can be justified by the fact that cognitive anxiety causes uncertainty with oneself and negative expectations about the possible results. ${ }^{13}$

According to Jordet, ${ }^{14}$ the best predictor for cognitive anxiety would be the athlete's experience, and the more experience the competitors have the lower the rates of cognitive anxiety, which is in agreement with the findings of our study, considering that adult medalists presented higher indices of this state than juvenile medalists.

The results obtained reinforce the thesis that high-performance adult athletes better manage anxiety than juveniles because they present a higher level of maturity and more experience in competitive sports. ${ }^{15,16}$ As an example, adult boxer medalists presented higher scores of cognitive anxiety than the non-medalists. On the other hand, juvenile non-medalist athletes presented higher levels of cognitive anxiety than the medalists.

The levels of somatic anxiety showed significant differences between the juvenile medalists and the other groups ( $p=0.038)$. Levels of self-confidence were high (Juvenile NM =29.42, Adult NM = 26.14, Juvenile Med = 31.59 and Adult Med = 28.91); there were no significant differences between groups despite juvenile medalists presenting higher values than the other athletes.

On somatic anxiety, the scores emphasize that high levels would be associated with sports failure. ${ }^{14}$ Therefore, in somatic anxiety, experience would be a good indicator of this manifestation. In this sense, increasing the athlete's age tends to decrease the chances of presenting great variations in the anxiety of these athletes. ${ }^{17}$ Greater maturity would be related to a greater conviviality with the competitive scenario, though this condition has been contradicted by Gonçalves and Belo, ${ }^{17}$ regarding the anxiety-trait in young athletes, who did not observe statistically different age factor and experience in combat modalities. However, in the somatic anxiety levels there were significant differences between juvenile medalists and the other groups. ${ }^{17}$

Comparatively, Gonçalves and Belo ${ }^{17}$ affirms that there is a relationship between anxiety and performance and that this relationship seems to vary according to several other factors, such as type of sport, task difficulty, personality characteristics, among others. The practice 
of a competitive sport would bring with it some particularities such as confrontation, demonstration, comparison, and constant evaluation of participants, making the competition a situation in which the development and performance of athletes are always compared with existing patterns. ${ }^{18}$

Parnabas et al. ${ }^{19}$ stated that at the time of the medal match, anxiety may exert influence on the athlete: those with greater emotional control would have better results at the moment of competition. Very high levels of anxiety can inhibit athletic performance because athletes tend to distort external perception, causing adverse reactions at decisive moments, especially in combat sports, as the athlete's reaction time and decision making are incisive in the result.

Anxiety is part of the daily lives of several people at different times in their lives and athletes come across it at all times. Thus, athletes tend to have differentiated levels of anxiety, be they high or low, at various times. These anxiogenic levels may vary depending on the situation. ${ }^{20}$ Therefore, it has been demonstrated that there should be an ideal level of anxiety for each athlete, considering that the state of intensity should be compatible with the nature of the activity, so that favorable results can be obtained. ${ }^{17}$
In this sense, high-performance boxing athletes in Brazil should not only enjoy physical, technical, tactical, nutritional, and medical preparation, but also psychological ${ }^{16}$ preparation. This corroborates the findings of our study, taking into account the results obtained recently by Brazilian boxers in the men's junior category who participated in the Continental Championship held in May 2018 in Colorado Springs, USA. On the occasion, they won four gold, one silver, and three bronze medals. The good performance displayed by the Brazilian youthful male boxers has recently been confirmed: the team was crowned champions with five gold and three silver medals in the 9th Belt Gold Cup held in Ecuador in June 2018. These are the best results by a Brazilian team in the base categories. ${ }^{21}$

\section{CONCLUSION}

From this study we can conclude that psychological factors such as cognitive anxiety tend to influence competitive outcomes, as athletes who are medalists tend to present less cognitive anxiety than non-medal athletes.

All authors declare no potential conflict of interest related to this article

AUTHORS' CONTRIBUTIONS: Each author made significant individual contributions to this manuscript. AAA: was the main researcher, responsible for the concept/design, data collection, data analysis/interpretation and drafting the article; DGM, DSS, and CFTC: participated in the concept/design, data analysis/interpretation and drafting the article; FJA, RFS and JLS: performed the statistical analysis and participated in the data interpretation, drafting the article and critical revision of the article; LMVS and ANS: participated in the data analysis/interpretation, drafting the article and critical revision of the article; FJA and MDS: contributed to the concept/design and participated in the data analysis/interpretation and critical revision of the article. All authors reviewed and approved the final version of the manuscript.

\section{REFERENCES}

1. Fletcher $D$, Arnold A. Stress in sport: the role of the organizational environment. In:The Organizational Psychology of Sport. London: Routledge, 2016. 101-18.

2. Schinke RJ, McGannon KR, Smith B. Routledge international handbook of sport psychology. London: Routledge, 2016.

3. Bali A. Psychological factors affecting sports performance. Int J Phys Educ Sports Health. 2015;1(6):92-5.

4. Georgios Z. Image evaluation of karate athletes. J Phys Edu Sport. 2016;16(3): 850-6.

5. Rice SM, Purcell R, De Silva S, Mawren D, McGorry PD, Parker AG. The mental health of elite athletes: a narrative systematic review. Sports Med. 2016;46(9):1333-53.

6. Garg SK. Evolving paradigm of illnesses presented to medical Intensive Care Unit in body builders: Cases from tertiary care center. Indian J Crit Care Med. 2015;19(4):227-9.

7. McIntosh AS, Patton DA. Boxing headguard performance in punch machine tests. Br J Sports Med. 2015;49(17):1108-12.

8. Chaabène $H$, Tabben $M$, Mkaouer $B$, Franchini $E$, Negra $Y$, Hammami $M$, et al. Amateur boxing: physical and physiological atributes. Sports Med. 2015;45(3):337-52.

9. Norman RE, Moreau BJ, Welker KM, Carré JM. Trait anxiety moderates the relationship between testosterone responses to competition and aggressive behavior. Adapt Hum Behav Physiol. 2015;1(3):312-24

10. Borg G. Perceived exertion as an indicator of somatic stress. Scand J Rehab Med. 1970;2(2):92-8.

11. Gill DL, Williams L, Reifsteck EJ. Psychological dynamics of sport and exercise. 4th ed. Champaign, IL: Human Kinetics, 2017.
12. Weinberg RS, Gould D. Foundations of sport and exercise psychology. 7th ed. Champaing, IL: Human Kinetics, 2018.

13. Moran AP. The psychology of concentration in sport performers: a cognitive analysis. Exerter, UK: Psychology Press, 2016.

14. Jordet G. Psychological characteristics of expert performers. In: Routledge handbook of sport expertise. Routledge, 2017. p. 132-46.

15. Slimani M, Miarka B, BrikiW, Cheour F. Comparison of mental toughness and power test performances in high-level kickboxers by competitive success. Asian J Sports Med. 2016;7(2):e30840.

16. Miarka B, Fukuda HD, Del Vecchio FB, Franchini E. Discriminant analysis of technical-tactical actions in high-level judo athletes. Int J Perf Anal Sport. 2016;16(1):30-9.

17. Gonçalves MP, Belo RP. Competitive anxiety-traits: differences in gender, age, experience in competitions and sports in young athletes. Psicol USF. 2017;12(2):301-7

18. Rice SM, Purcell R, De Silva S, Mawren D, McGorry PD, Parker AG. The mental health of elite athletes: a narrative systematic review. Sports Med. 2016;46(9):1333-53.

19. Parnabas V, Parnabas J, Parnabas AM. The influence of cognitive anxiety on sport performance among taekwondo athletes. Inter J Indian Psychol. 2015;2:56-63.

20. Gubbels J, van der Stouwe T, Spruit A, Stams GJ. Martial arts participation and externalizing behavior in juveniles: a meta-analytic review. Aggres Viol Beh. 2016;28:73-81.

21. Confederação Brasileira de Boxe (CBBoxe). História do boxe olímpico, 2018. [acesso em 2019 jan 10]. Disponível em: http://www.cbboxe.com.br/sitenovo/Historia-Boxe-Olimpico. 